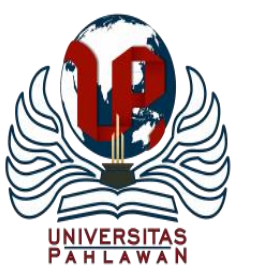

Jurnal Basicedu Volume 4 Nomor 4 Tahun 2020 Halm. 880 - 888

JURNAL BASICEDU

Research \& Learning in Elementary Education

https://jbasic.org/index.php/basicedu/index

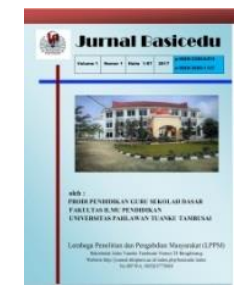

\title{
Teacher's Efforts in Improving Students' Mathematics Learning Achievement for Grade 4 Students
}

\author{
Nur Ni'matul Khasanah ${ }^{1}$, Rahmat Hariyadi ${ }^{2}$ \\ Pendidikan Guru Madrasah Ibtidaiyah, Fakultas Tarbiyah Ilmu Keguruan, IAIN Salatiga, Jawa Tengah ${ }^{1}$ \\ Dosen Pendidikan Guru Madrasah Ibtidaiyah, Fakultas Tarbiyah Ilmu Keguruan, IAIN Salatiga ${ }^{2}$ \\ E-mail : nurnimatulkhasanah1@gmail.com ${ }^{1} \underline{\text { rahmathariyadi@gmail.com }}{ }^{2}$
}

\begin{abstract}
Abstrak
Tujuan yang hendak dicapai dalam penelitian ini adalah untuk mengetahui bagaimana upaya guru dalam meningkatkan prestasi belajar matematika siswa kelas IV di (Madrasah Ibtidaiyah Negeri) MIN Salatiga dan (Madrasah Ibtidaiyah) MI Ma'arif Pulutan Salatiga tahun ajaran 2018/2019. Jenis penelitian ini adalah deskriptif kualitatif dengan menggunakan teknik observasi, wawancara, dan dokumentasi untuk mengumpulkan data. Analisis data pada penelitian ini menggunakan triangulasi teknik, triangulasi waktu dan triangulasi sumber. Hasil penelitian menunjukkan bahwa upaya guru dalam meningkatkan prestasi belajar matematika kelas IV pada kedua madrasah yakni upaya dalam memotivasi siswa dengan menciptakan suasana kelas yang kompetitif, upaya dalam membimbing siswa melalui les malam dan ekstra OSN (Olimpiade Sains Nasional), upaya dalam proses pelaksanaan pembelajaran melalui metode sarapan pagi matematika dan quiz di awal pembelajaran, menggunakan metode dan model pembelajaran yang variatif, menggunakan berbagai permainan dalam pembelajaran dan upaya dalam evaluasi yaitu ulangan harian, PTS (Penilaian Tengah Semester) dan PAS (Penilaian Akhir Semester).
\end{abstract}

Kata kunci: upaya guru, peningkatan prestasi belajar, matematika

\begin{abstract}
The purpose of this research is to find out how the teacher's efforts in improving mathematics learning achievement of $4^{\text {th }}$ grade students in (Madrasah Ibtidaiyah Negeri) MIN Salatiga and (Madrasah Ibtidaiyah) MI Ma'arif Pulutan Salatiga 2018/2019 school year. This type of research is a qualitative descriptive research using observation, interviews, and documentation to collect data. Data analysis in this research used technical triangulation, time triangulation and source triangulation. The results showed that the teacher's efforts to improve mathematics learning achievement in the $4^{\text {th }}$ grade students in both schools, namely efforts to motivate students by creating a competitive classroom atmosphere, efforts in guiding students through night courses and OSN (Olimpiade Sains Nasional or National Science Olympiad), efforts in the process of implementing learning through the mathematics breakfast method and quiz at the beginning of learning, using varied learning methods and models, use a variety of games in learning and efforts in evaluation namely daily tests, PTS (Penilaian Tengah Semester or Mid-Term Assessment) dan PAS (Penilaian Akhir Semester or Final-Term Assessment).
\end{abstract}

Keywords: teacher's effort, improving learning achievement, mathematics

Copyright (c) 2020 Nur Ni'matul Khasanah, Rahmat Hariyadi

$\triangle$ Corresponding author :

Address : Suruh, Semarang Regency, Central Java

ISSN 2580-3735 (Media Cetak)

Email : nurnimatulkhasanah1@gmail.com

ISSN 2580-1147 (Media Online)

Phone : 081228403866

DOI : https://doi.org/10.31004/basicedu.v4i4.443 


\section{INTRODUCTION}

High student learning achievement is one of the factors that shows that a school has good quality Human Resources in it. Learning achievement is the result of learning achieved in each learning activity. The learning process experienced by students produce changes in knowledge, skills, values and attitudes. The learning achievement is a measurement administered by the teacher to know the value or score obtained by the students. Therefore, teachers will be able to determine students' ability (Shodiq, 2017: 1).

A school that has good quality will be able to compete with schools or other school in this global era where knowledge of mathematical logic and technology is very important to know, besides knowledge of Islam as a true way of life. Therefore, this is where the importance of a school must have high learning achievements in order to compete with other schools, especially public schools. Learning achievement is the mastery of knowledge or skills developed through subjects. Learning achievements generally relate to aspects of knowledge, while learning outcomes include aspects of character formation of students. Learning achievement is a perennial problem in the history of human life, because throughout the span of human life always pursue achievement according to their respective fields and abilities (Zainal Arifin, 2011: 12).

The success of students in learning is inseparable from the quality of teaching, as well as various other efforts made by teachers both outside and in the classroom (Rosdiati, 2017: 315).
Teachers who have a sincere heart and always educate with the heart will always try everything that is best for their students. So it can be said how sincere and persistent a teacher is in educating his students, the more optimal the learning achievement obtained by students. Learning mathematics requires an appropriate strategy so that the results achieved are maximum and affect student learning achievement (Faisal, 2016: 444).

Good learning achievements will be obtained by every student when students and teachers have chemistry in the form of comfort during the Teaching and Learning Process (KBM) in the classroom, happy in the process of KBM and every material delivered by the teacher can hit the hearts of students because the teacher always teaches with heart. To realize this, the teacher must always be creative and continue to innovate and provide encouragement, motivation, appreciation and guidance which are all held by the role of a teacher in the class.

Table 1. Average Grades of Mathematics Subjects in Class $4^{\text {th }}$ MIN Salatiga and MI Ma'arif Pulutan

\begin{tabular}{ccc}
\hline \multicolumn{2}{c}{ Average Grades } \\
\hline Score & MIN Salatiga & MI Ma’arif Pulutan \\
PTS 1 & 39,4 & 60,4 \\
\hline PAS 1 & 72,4 & 64,6 \\
\hline PTS 2 & 76,0 & 75,4 \\
\hline
\end{tabular}

Mathematics achievement of $4^{\text {th }}$ grade students in the school has increased quite rapidly in the 2018/2019 school year (Table 1). If all previous studies only focus on improving students' mathematics learning achievement through the use 
of models, games, and learning media, then the novelty of this research lies in the full presentation of what efforts are made by teachers to improve student mathematics learning achievement. Thus, it is very important to explore and examine the efforts of teachers in improving student learning achievement in the $4^{\text {th }}$ grade in MIN Salatiga and MI Ma'arif Pulutan.

\section{METHODS}

The type of method that the writer used in this research is descriptive qualitative. Qualitative method is a research procedure that produces descriptive data in the form of written or oral words from people and observable behavior (Moleong, 2009: 4). This research was conducted at MIN Salatiga and MI Ma'arif Pulutan Salatiga which were comparable in terms of the quality of education and learning. The reason for choosing the object of research in the school is because the mathematics learning achievement of $4^{\text {th }}$ grade students in the two schools in the 2018/2019 school year both increased well.

Data collection procedures used in this study were observation, interviews and documentation. Data validity test in this study uses source triangulation, time triangulation and technique triangulation. Triangulation of data sources to test the credibility of the data is done by conducting interviews with teachers and grade $4^{\text {th }}$ students. While the triangulation of techniques to test the credibility of the data is done by checking the data obtained from the same data source with different techniques.

\section{RESULT AND DISCUSSION}

Learning comes from the word learning, learning is a business process carried out by someone to obtain a new change in behavior as a whole, as a result of his own experience in interactions with the environment (Slameto, 2009: 2). Mathematics is one of the subjects that occupies an important role in the field of education. Mathematics is a universal science that underlies the development of modern technology, has an important role in various disciplines and advances human thinking (Hartati, 2015: 262).

Mathematics subjects need to be given to all students starting from elementary school to equip students with the ability to think logically, analytically, systematically, critically, creatively and the ability to work together (Kasri, 2018: 320). Mathematics learning is a teaching and learning process built by teachers to develop students' thinking creativity that can enhance the ability to construct new knowledge in an effort to increase good mastery of mathematical material (Susanto, 2013: 186).

\section{Teacher's Efforts in Improving Mathematics}

\section{Learning Achievement in Madrasah Ibtidaiyah}

1) Efforts in Motivating Students

Motivating is one of the factors that also determines the effectiveness of learning. Students will study earnestly if they have high motivation. In this connection the teacher is required to have the ability to arouse student learning motivation so that it can achieve learning goals (Mulyasa, 2007: 112). 
2) Efforts in Guiding Students

Guidance in the process of education in schools is the process of providing assistance to students so that he as a person has a correct understanding of his personal self and the world around him, making decisions to move forward optimally in his development and can help himself, confront and solve his problems (Bahroin, 2017: 46).

3) Efforts in Implementing the Learning Process The process or implementation of education is an effort in realizing educational goals. The teaching and learning process is the core of educational activities in schools. In the education process this is the importance of the ways or methods of how the skills or knowledge will be conveyed to students.

4) Efforts in Student Evaluation

Evaluation is one of the important components and stages that must be taken by the teacher to determine the effectiveness of learning. The results obtained from the evaluation can be used as feedback (feedback) for teachers in improving and perfecting learning programs and activities (Zainal Arifin, 2011: 02).

Researchers will describe the efforts of teachers in improving mathematics learning achievement of $4^{\text {th }}$ grade students in MIN Salatiga and MI Ma'arif Pulutan Salatiga as research objects. Both of these schools have improved mathematics learning achievements in the 2018/2019 school year. The researcher applied observation, interview, and documentation when the reseach conducted the research as technique to collect data. The informant of this research was the teachers of $4^{\text {th }}$ grade teachers from each school which was called as the object of research.

\section{MIN Salatiga}

The time of research at MIN Salatiga began on February 15, 2018 until March 15, 2018. The subjects in this study were teachers and $4^{\text {th }}$ grade students, amounting to 31 students. The efforts made by the Salatiga MIN teacher are as follows:

1) Efforts in Motivating Students

The $4^{\text {th }}$ grade teacher creates a strong class atmosphere for the spirit to compete, so students compete with their peers. For example, after completing daily tests, PTS, PAS and so on each student is required to memorize the value obtained, then when the teacher will input grades, each student is summoned according to the presence and mentions the value obtained loudly and confidently. So that when students hear their friends get higher grades than other students, there is a sense of wanting to compete to be better than their peers. And students who have low grades will feel embarrassed so that he will study harder or at least he will listen to the teacher's explanation well in the classroom.

2) Efforts in Guiding Students

The teacher holds evening courses on Tuesdays and Thursdays at school, after evening prayers' from 19:00 to 20:00 WIB. In this tutoring class, the teacher provides a special opportunity for students to ask 
questions about materials they have not understood in the learning process.

3) Efforts in Implementing the Learning Process

a) Moving the mathematics learning at the beginning of the lesson.

If on that day the mathematics lesson schedule is at the $4^{\text {th }}$ hour the class teacher can move the mathematics lesson at the beginning of the lesson. The reason teachers move mathematics in the morning so that students and teachers learn mathematics is fresh and still has a high focus.

b) Mathematical breakfast Mathematical breakfast where the teacher gives 5 math questions to students every morning at the start of spontaneous learning. The teacher aims to re-stimulate students' memories of the material learned on the previous day and accustom students to always be ready to accept challenges.

c) Completing one semester material in a half semester.

d) In order for students to have a deep understanding, the teacher teaches mathematics material one semester in half the semester then repeats the mathematics material in the next half semester.

e) Familiarize the classroom environment that loves mathemathics.

In the classroom, the teacher gives wall decorations in the form of multiplication in a banner, large size division with the aim when working on the problem, students can quickly finish it without being interrupted for a few seconds to count multiplication or division. The teacher instills in the mindset of students if mathematics is easy to do so it makes students like math.

f) Using various learning models and methods.

The learning model used by the teacher is;

(1) Active learning model

(2) Cooperative learning model

(3) Peer teaching method

(4) Lecture method

(5) Question and answer method

(6) Drill method

g) Using a variety of games in learning, including: Fun learning methods that can affect student learning outcomes are play methods.

1) Choosing 3 male students and 3 female students.

The teacher randomly assigns 6 students consisting of 3 male students and 3 female students. Then a male and female student representative is asked to do the suit, and the winner gets the assignment to make the questions and the loser is asked to work on the questions made by the winning student.

2) Using the game Sing Sing So The game Sing Sing So is applied by singing the song while pointing the student in sequence from the front / back seat, the sequence goes to the left side until the song runs out. 
Students who are appointed when the song runs out that will work on the questions given by the teacher.

3) Appoint the student to work on the problem in front of the class using the date or month at the time.

4) Efforts in Learning Evaluation

Implementing an even odd system to work on problems. Students who have odd attendance numbers work on odd questions only and students who have even attendance numbers work on even questions.

In summary, the researcher presents the table of the $4^{\text {th }}$ grade MIN Salatiga teacher's efforts in improving students' mathematics learning achievement below:

Table 2. Grade $4^{\text {th }}$ Teachers' Efforts in MIN Salatiga

\begin{tabular}{|c|c|c|}
\hline No & $\begin{array}{c}\text { Teacher's } \\
\text { Effort }\end{array}$ & MIN Salatiga \\
\hline 1 & $\begin{array}{l}\text { Motivating } \\
\text { students }\end{array}$ & $\begin{array}{l}\text { Creating a competitive class } \\
\text { atmosphere }\end{array}$ \\
\hline 2 & $\begin{array}{l}\text { Guiding } \\
\text { students }\end{array}$ & $\begin{array}{l}\text { Holds tutoring at night on } \\
\text { Tuesdays and Thursdays at school }\end{array}$ \\
\hline 3 & $\begin{array}{l}\text { Learning } \\
\text { Implementat } \\
\text { ion Process }\end{array}$ & $\begin{array}{l}\text { a. Transferring mathematics } \\
\text { learning at the beginning of the } \\
\text { lesson } \\
\text { b. Mathematical breakfast } \\
\text { c. Completing material one } \\
\text { semester in half a semester } \\
\text { d. Familiarizing the classroom } \\
\text { environment that loves } \\
\text { mathematics } \\
\text { e. Using a variety of learning } \\
\text { models and methods } \\
\text { f. Using various games in } \\
\text { learning }\end{array}$ \\
\hline 4 & $\begin{array}{l}\text { Evaluating } \\
\text { Students }\end{array}$ & $\begin{array}{l}\text { Implementing an even odd system } \\
\text { to work on problems }\end{array}$ \\
\hline
\end{tabular}

\section{Ma'arif Pulutan}

The time of research at MI Ma'arif Pulutan began on March 26 until April 26, 2018. The subjects in this research were teachers and $4^{\text {th }}$ grade students, amounting to 28 students. The efforts made by the $4^{\text {th }}$ grade teacher MI Ma'arif Pulutan Salatiga are as follows:

1) Efforts in Motivating Student

At the beginning of each lesson the teacher gives an apperception about the reasons for learning mathematics, the intention to study properly, how to make parents proud of the achievements of students.

2) Efforts in Guiding Student

The teacher holds an extra OSN (National Science Olympiad) which is held once a week every Tuesday after finishing learning in class. Teachers often provide quick moves to solve mathematical problems in this extra OSN.

3) Efforts in Learning Implementation Process

a) An impromptu quiz of 2 or 3 questions at the beginning of the lesson.

The $4^{\text {th }}$ grade teacher gives an impromptu quiz about two or three questions before starting mathematics. Students who can answer will get special points in the form of additional grades from the teacher.

b) Using varied learning models and methods.

The learning model used by he teacher is;

(1) Active learning model

(2) Cooperative learning model

(3) Peer teaching learning method 
(4) Question and answer method

c) Drill method

d) Using varieties of games in learning, including:

(1) Appoint one student to come forward to work on the problem then asked to appoint another student to do the exercise in fron of the class, until all of the answers have been answered.

(2) Teachers often ask students with, "Who has different answer?" Students with different answer should rise their hand and then discussed it.

(3) Always use available media in the surrounding environment.

4) Efforts in Learning Evaluation

Implement Daily Tests, Mid-Semester Assessment (PTS) and Final Semester Assessment (PAS) in an orderly and individually manner.

In summary, the researcher presents the table of the efforts of the $4^{\text {th }}$ grade MI Ma'arif Pulutan teacher in improving the mathematics learning achievement of students shown Tabel 3.

In general, the efforts of teachers in improving mathematics learning achievement in the two schools have in common in an effort to motivate students, in guiding students, in the process of implementing learning and in the process of learning evaluation. However, due to geographical conditions, the envir onment and different human resources, the $4^{\text {th }}$ grade teachers in each school adjust it so that these efforts can be carried out properly and optimally. The similarity of the efforts made by grade $4^{\text {th }}$ teachers in MIN Salatiga and MI Ma'arif Pulutan shown in Table 4.

Table 3. Grade $4^{\text {th }}$ Teachers' Efforts in MI Ma'arif Pulutan

\begin{tabular}{|l|l|l|}
\hline No & $\begin{array}{l}\text { Teachers' } \\
\text { Effort }\end{array}$ & MI Ma'arif Pulutan \\
\hline 1 & $\begin{array}{l}\text { Motivating } \\
\text { students }\end{array}$ & $\begin{array}{l}\text { Give apperception about the } \\
\text { reasons for studying mathematics, } \\
\text { intention to study properly, how to } \\
\text { make parents proud of the } \\
\text { achievements of students; one of } \\
\text { them is by being serious in learning } \\
\text { and studying in school. }\end{array}$ \\
\hline 2 & $\begin{array}{l}\text { Guiding } \\
\text { students }\end{array}$ & $\begin{array}{l}\text { Hold extra OSN (National Science } \\
\text { Olympiad) every Tuesday. }\end{array}$ \\
\hline 3 & $\begin{array}{l}\text { Implementati } \\
\text { on of the } \\
\text { Learning } \\
\text { Process }\end{array}$ & $\begin{array}{l}\text {-Hold an impromptu quiz 2 or 3 } \\
\text { questions at the beginning of } \\
\text { learning } \\
\text {-Always use available media in the } \\
\text { surrounding environment } \\
\text {-Using a variety of learning models } \\
\text { and methods } \\
\text {-Using various games in learning }\end{array}$ \\
\hline 4 & $\begin{array}{l}\text { Learning } \\
\text { evaluation }\end{array}$ & $\begin{array}{l}\text { Daily, PTS and PAS tests are } \\
\text { orderly and individually }\end{array}$ \\
\hline
\end{tabular}

To improve student learning achievement begins with the teacher reminding about the intention to study properly through apperception every morning, making students feel comfortable and happy and interested in mathematics. How to make happy, comfortable and interested can be applied by using various methods, models and games in the Teaching and Learning Process (KBM). Furthermore, more important than that all, the teacher's explanation must be clear, repetition of the material so that deeper understanding must also be clear, the addition of services outside the 
teaching and learning process in the classroom such as extra or tutoring.

Table. 4 Equations of Teacher's Efforts in Both Schools

\begin{tabular}{|l|l|l|}
\hline No & \multicolumn{1}{|c|}{ MIN Salatiga } & \multicolumn{1}{|c|}{ MI Ma'arif Pulutan } \\
\hline 1. & $\begin{array}{l}\text { Holds tutoring at } \\
\text { night on Tuesdays } \\
\text { and Thursdays at } \\
\text { school. }\end{array}$ & $\begin{array}{l}\text { There is an extra } \\
\text { OSN that discusses } \\
\text { science and } \\
\text { mathematics. }\end{array}$ \\
\hline 2. & $\begin{array}{l}\text { Mathematical } \\
\text { breakfast: 5 math } \\
\text { problems every } \\
\text { morning at the } \\
\text { beginning of } \\
\text { learning. }\end{array}$ & $\begin{array}{l}\text { An impromptu quiz } \\
\text { of } 2 \text { or } 3 \text { questions at } \\
\text { the beginning of the } \\
\text { lesson. }\end{array}$ \\
\hline 3. & $\begin{array}{l}\text { Using the peer } \\
\text { teaching method }\end{array}$ & $\begin{array}{l}\text { Using the peer } \\
\text { teaching method }\end{array}$ \\
\hline 4. & $\begin{array}{l}\text { Appoint student to } \\
\text { work on problems } \\
\text { ahead using dates or } \\
\text { months }\end{array}$ & $\begin{array}{l}\text { Appoint one student } \\
\text { to come forward to } \\
\text { work on the problem } \\
\text { then the child who } \\
\text { has advanced is } \\
\text { asked to appoint } \\
\text { another friend to do } \\
\text { the exercises in } \\
\text { front, and so on until } \\
\text { the problem runs out }\end{array}$ \\
\hline 5. & $\begin{array}{l}\text { Teachers often ask } \\
\text { students when asked } \\
\text { to work on } \\
\text { problems: who has } \\
\text { different answers? } \\
\text { What is different is } \\
\text { told to move } \\
\text { forward. } \\
\text { Teachers often ask } \\
\text { students when asked } \\
\text { to work on } \\
\text { problems: who has } \\
\text { different answers? } \\
\text { What's different is } \\
\text { please show your } \\
\text { hand then discuss it. }\end{array}$ \\
\hline
\end{tabular}

This research was conducted in two schools, so it is hoped that the results of comparative research that have many similarities can be utilized or used by elementary / MI teachers wherever they are. The weakness of this research is the lack of depth of the variables discussed because there are four sub-chapters that must be explained. Current research contributions can add insight and references to teachers or prospective teachers in teaching mathematics to grade $4^{\text {th }}$ students at the elementary / MI level. Subsequent research refined teacher challenges in improving students' mathematics learning achievement with more focused variables and increasing more complex but profound ones. For example, only discussing the efforts of teachers in motivating students, or the efforts of teachers in evaluating learning.

\section{BIBLIOGRAPHY}

Arifin, Z. (2013.). Evaluasi Pembelajaran. PT Remaja Rosdakarya.

Arikunto, S. (2010). Prosedur Penelitian Suatu Pendekatan Praktik. PT Rineka Cipta.

Bealla, F. R. N. (2015.). Teachers' Efforts to Improve Learning Mathematics Results using Games for 3rd Students at SD N 2 Pusporenggo Kec. Musuk Kab. Boyolali. Jurnal Ilmiah Mitra Swara Ganesha, 2, 15.

Faisal. (2016). Efforts To Improve Mathematic Learning Outcome Of The Students At Sdn Cepit By Using Media Concrete Objects. Jurnal Pendidikan Guru Sekolah Dasar. 5 , 444.

Hartati, H. (2015). Upaya Peningkatan Prestasi Belajar Matematika Siswa Kelas VI SD Negeri 21 Palu Materi FPB dan KPK Melalui Metode Pembelajaran Kooperatif Tipe Numbered Heads Together (NHT). Jurnal Kreatif Tadulako Online, 4(10), 262.

Heruman. (2010). Model Pembelajaran Matematika di Sekolah Dasar. PT Remaja Rosdakarya. 

Nur Ni'matul Khasanah, Rahmat Hariyadi

DOI: https://doi.org/10.31004/basicedu.v4i4.443

Kasri. (2018.). Peningkatan Prestasi Belajar Matematika melalui Media Puzzle Siswa Kelas I SD. Jurnal Pendidikan: Riset \& Konseptual, 320.

Moeleong, L. J. (2009). Metodologi Penelitian Kualitatif Edisi Revisi. PT Remaja Rosdakarya.

Mulyasa, E. (2017). Menjadi Guru Profesional. PT Remaja Rosdakarya.

Rosdiati. (2017). Upaya Meningkatkan Hasil Belajar Matematika Melalui Model Pembelajaran Kooperatif Tipe STAD Siswa Sekolah Dasar. Suara Guru: Jurnal Ilmu Pendidikan Sosial, Sains, Humaniora, 3(3), 315.

Shodiq, A. (2017). The Effectiveness of Contextual Teaching and Learning to Improve Achievement in Basic Grammar Class at Kampung Inggris Language Center Pare Kediri. Kampung Inggris Language Center Pare Kediri.

Slameto. (2009). Belajar dan Faktor-Faktor Yang Mempengaruhinya. PT Rineka Cipta.

Sugiyono. (2015). Metode Penelitian Kuantitatif, Kualitatif Dan $R \& D$. Alfabeta.

Susanto, J. (2012). Pengembangan perangkat pembelajaran berbasis lesson study dengan kooperatif tipe numbered heads together untuk meningkatkan aktivitas dan hasil belajar IPA di SD. Journal of Primary Education, 1(2). 